Proc. Estonian Acad. Sci. Geol., 2001, 50, 3, 190-205

\title{
ASPECTS OF THE DOLOMITIZATION OF THE MÕHKÜLA BEDS (SILURIAN, ESTONIA)
}

\author{
Aada TEEDUMÄE ${ }^{\mathrm{a}}$, Toivo KALLASTE ${ }^{\mathrm{a}}$, and Tarmo KIIPLI ${ }^{\mathrm{b}}$ \\ ${ }^{\text {a }}$ Institute of Geology, Tallinn Technical University, Estonia pst. 7, 10143 Tallinn, Estonia; \\ teedumae@gi.ee \\ b Mining Institute of Tallinn Technical University, Kopli 82, 10412 Tallinn, Estonia \\ Received 12 December 2000, in revised form 28 March 2001
}

\begin{abstract}
The dolomites of the Mõhküla Beds represent the uppermost middle Llandovery in the northeastern, marginal part of the Baltic Palaeobasin. Secondary dolomitization has changed the primary composition of rocks, but according to the geological data available they originate from the normal-marine sediments of the shelf facies.

$\mathrm{X}$-ray diffraction, X-ray fluorescence, and titration analyses were applied to study the chemical composition of rocks and differences in the dolomitizing environment. The $\mathrm{CaCO}_{3} / \mathrm{MgCO}_{3}$ molar ratio and lattice parameters of dolomites, irrespective of the content of insoluble residue or the texture of rocks, are close to those of ideal dolomites. Compared to limestones dolomites are depleted in $\mathrm{Sr}$ and enriched in Mn. The concentrations and correlations of these elements vary by lithological varieties along the section, which supports the suggestion that there was no unique dolomitizing fluid and the dolomitization began soon after the deposition. The geochemistry of dolomites is almost consistent with dolomitization by normal or modified (dilute) sea water. In general, dolomitization correlates with regression. The area favourable for dolomitization is related to the inner shelf, migrating in accordance with the fluctuation of sea level and oscillation of the shoreline.
\end{abstract}

Key words: Silurian, dolomitization, lithology, Palaeozoic dolomite, X-ray diffraction, Estonia.

\section{INTRODUCTION}

Silurian (Llandovery, Wenlock), primarily normal-marine carbonate sediments of shoal and open shelf facies have undergone intensive dolomitization. As a result, an extensive body of dolomites has formed, cross-cutting different facies and depositional sequences in central and western Estonia (Vishnyakov 1956; Jürgenson 1970; Bityukova et al. 1998). In mainland Estonia the upper part of this body (Muhu Formation, Wenlock) consists of nearly stoichiometric dolomites 
(Teedumäe et al. 1999). Its middle part is represented by the Mõhküla Beds. The lithostratigraphic unit corresponding to the present Mõhküla Beds (Llandovery, Silurian) was originally distinguished (Jürgenson 1966) as the Mõhküla Member in the lowermost part of the Adavere Stage (upper Llandovery). According to the current classification (Nestor 1995, 1997), the Mõhküla Beds are included into the underlying Raikküla Stage (middle Llandovery, Nurmekund Formation) as they are separated from the rest of the Adavere Stage by a disconformity.

The Mõhküla Beds were selected for the investigation of massive pervasive dolomitization of the Silurian rocks against the background of the evolution of the Baltic Palaeobasin in the middle Llandovery (Nestor \& Einasto 1997). The present research constitutes a sequel to the previous study of Teedumäe et al. (1999) and was carried out within the framework of the research project 0140226Bs98 "Lithological-mineralogical preconditions for the rational use of the bowels of the earth in Estonia".

\section{GEOLOGICAL SETTING}

During the Silurian, the sea gradually retreated and the Baltic Palaeobasin evolved from an epicontinental to a gulf-like pericratonic sea (Nestor \& Einasto 1997). The facies belts gradually shifted southwestwards. In the middle Llandovery the present-day Estonia was situated mostly within the marginal part of the basin, dominated by shallow-water carbonate sediments with numerous discontinuity surfaces.

The Mõhküla Beds are distributed in central Estonia (Fig. 1) and represent the uppermost part of the middle Llandovery (Raikküla Stage) on the northeastern margin of the Baltic Palaeobasin. These beds were formed in the shoal to open shelf (upper ramp) conditions at the end of the differentiation stage (late Caradoc-middle Llandovery) of the basin (Nestor \& Einasto 1997). This stage marked the transition from transgressive to regressive phase in the basin development, but also the transition from humid, moderate climatic conditions to arid, subtropical conditions. The influx of fine terrigenous material fluctuated cyclically and the stage ended with an extensive local sedimentation break and denudation of the earlier deposited strata in the marginal parts of the palaeobasin. One area of denudation occurred in western Estonia, where the erosional hiatus cuts down besides the Mõhküla Beds a remarkable part of the underlying beds, and the late Llandovery (Adavere Stage) sediments transgressively overlap different middle Llandovery strata (Raikküla Stage). Although there unconformity forms a single discontinuity surface, it supposedly results from small-scale transgressions and regressions against the background of progressive sea level drop. The local character of nondeposition and changeable extent of the deposition break were most probably of tectonic nature, induced by the beginning of the collision of the Laurentia and Baltica cratons (Nestor \& Einasto 1997). 


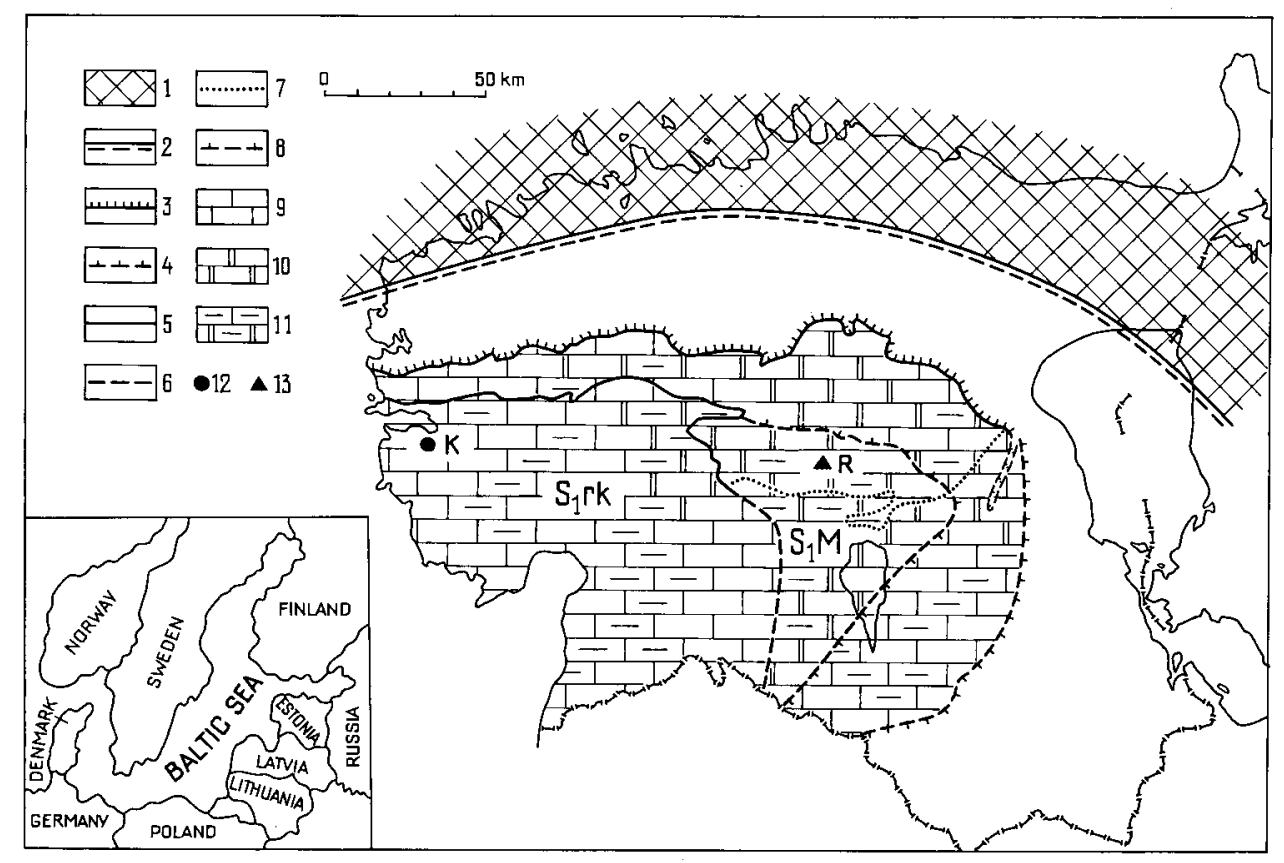

Fig. 1. Sketch map showing the lithological composition of the Raikküla Stage. Contours 3-8 after Nestor (1997, fig. 67); lithology of the outcrop after Teedumäe (1992, 1996); lithology of subsurface distribution modified from Jürgenson (1988). 1, land; 2, supposed shoreline; 3, contour of surface distribution; 4, contour of subsurface distribution; 5 , limit of the outcrop belt; 6 , limit of pre-Devonian erosion; 7, margin of the Devonian cover; 8, extension limit of the Mõhküla Beds; 9, limestone; 10, dolomite; 11, argillaceous limestone and dolomite; 12, borehole; 13, quarry; $\mathrm{S}_{1}$ rk, Raikküla Stage; $\mathrm{S}_{1} \mathrm{M}$, Mõhküla Beds; R, Rõstla quarry; K, Kirikuküla borehole.

The rocks of the Mõhküla Beds are fully dolomitized (Teedumäe 1996). Different sources of $\mathrm{Mg}$ have been suggested for Silurian secondary dolomites: (1) Devonian sediments (Jürgenson 1970), (2) hypersaline lagoonal waters (Vishnyakov 1956) or mixed fresh ground water and marine water of the northeastern part of the Devonian East European Basin (Kiipli 1983), and (3) the normal and modified (dilute) marine water of the northern part of the Silurian Baltic Basin (Teedumäe et al. 1999).

Secondary dolomitization has changed the primary composition of rocks, but the skeletal remains of fossils and lithological characteristics (see the description below) allow us to suggest the normal-marine origin of primary carbonates. The section of the Mõhküla Beds in Rõstla quarry begins with the argillaceous horizontal-bedded, fine-crystalline dolomite (originally calcareous-argillaceous mud), which upwards is replaced by wavy- to nodular-bedded, in some layers rich in skeletal debris fine- to coarse-crystalline dolomite (originally bioclastic calcareous mud), followed by fine-crystalline dolomite (originally calcareous mud). 


\section{Description of the Rõstla quarry section (from the surface)}

Interval

$0.0-3.0 \mathrm{~m}$

$3.0-5.7 \mathrm{~m}$

$5.7-6.2 \mathrm{~m}$

$6.2-7.8 \mathrm{~m}$

$7.8-9.1 \mathrm{~m}$

\section{Description}

Fine-crystalline, horizontal- or wavy-bedded, light purplemottled, yellowish dolomite with rare irregular small solution cavities, relicts of fossils and clayey intercalations. On some bedding planes bright white lenses (thickness $1-3 \mathrm{~cm}$ ) of silica concretions and nodules occur.

Medium- to coarse-crystalline, porous, greenish-grey dolomite with discontinuous, membraneous, greenish clayey intercalations, silicified skeletal debris and lenses (up to $5 \mathrm{~cm}$ thick) of silica. The majority of voids appear to be openings left by the dissolution of fossils (brachiopods, tabulate corals, etc.). The dolomite crystals inside the openings are yellowish. In places brownish impregnation spots can be observed.

Fine-crystalline, yellowish, nodular to seminodular, compact dolomite with reddish and greenish clayey membraneous intercalations.

Fine-crystalline, brownish, nodular compact dolomite with numerous multicoloured (reddish, brownish, greenish) clayey intercalations. Characteristic are rare voids of leached-out skeletal debris, silica nodules (diameter up to $7 \mathrm{~cm}$ ), brightwhite, up to $5 \mathrm{~cm}$ thick lenses or discontinuous interlayers of very rich in silicified fossils silica, and reddish-brown dispersing stripes on the contact of dolomite with clayey intercalations.

Fine-crystalline, horizontal-bedded argillaceous dolomite with lense-like, up to $5 \mathrm{~cm}$ thick and up to some metres long interlayers of coarse fossil debris. No crystals of dolomite occur in the voids of fossil debris. The cavities are rare outside the debris layer. The colour of dolomite is variegated, with greyishpurple and reddish-brown stripes and spots.

\section{MATERIAL AND METHODS}

Twenty-six dolomite samples (R1-R26) were collected from Rõstla quarry for the complex study of the chemical composition and X-ray diffractometry. In order to find out the trends of environmental differences, 41 limestone samples from the Kirikuküla core were subjected to X-ray fluorescence analysis (Fig. 1). The studied interval of the core is stratigraphically lower than the Mõhküla Beds, but lies directly beneath the erosional hiatus that cuts out the upper part of the Raikküla Stage (including the Mõhküla Beds) in western Estonia. 
$\mathrm{CaO}, \mathrm{MgO}$, and insoluble residue (henceforward i.r.) were analysed by titration. $\mathrm{Fe}_{2} \mathrm{O}_{3}$ (total), $\mathrm{Mn}, \mathrm{Sr}$, and $\mathrm{Pb}$ were analysed by the $\mathrm{X}$-ray fluorescence method with the VRA-30 analyser using an X-ray tube with a Mo anode at $50 \mathrm{kV}$ and $20 \mathrm{~mA}$. Calibration of $\mathrm{Mn}$ and $\mathrm{Fe}$ was based on internationally intercalibrated dolomite reference materials Es-4 and Es-11 without matrix corrections. In calibration of $\mathrm{Sr}$ some additional silicate and limestone reference materials were used and, accordingly, matrix corrections (Compton scattering method) were applied. The precision of analyses was determined from 10 replicate measurements: $\mathrm{Fe}_{2} \mathrm{O}_{3} \pm 0.005 \%, \mathrm{MnO} \pm 0.005 \%, \mathrm{Sr} \pm 2 \mathrm{ppm}$, and $\mathrm{Pb} \pm 3 \mathrm{ppm}$.

$\mathrm{X}$-ray diffractometry was carried out on a model HZG4 X-ray diffractometer. Dolomite stoichiometry was determined by measuring the position of the 104 peak using Si as a standard. The value $2.8840 \AA$ for $d_{104}$ of ideal dolomite was calculated on the basis of the composition of reference materials Es-4 (Estonia) and S1 (USSR).

\section{RESULTS AND DISCUSSION}

The $\boldsymbol{d}_{\mathbf{1 0 4}}$ value of dolomite varies from 2.8853 to $2.8876 \AA$ (Table 1 ). It is larger than that of ideal dolomite (2.8840 $\AA$, Teedumäe et al. 1999). No calcite, siderite, or rhodochrosite was revealed. The molar concentration of $\mathrm{CaCO}_{3}\left(m_{\mathrm{Ca}}\right)$ in dolomite was calculated as follows:

$$
\mathrm{mol} \% \mathrm{CaCO}_{3}=\frac{\left(d_{104}-2.8840\right)}{0.003}+50 .
$$

The titration analyses (Table 1) showed $1-2 \%$ excess of $\mathrm{CaO}$. Provided that additional $\mathrm{Ca}$ replaces $\mathrm{Mg}$, the calculated by (2) growth of the $d_{104}$ value is 0.0023-0.0047 ̊̊:

$$
\Delta d_{104}=m_{\mathrm{Ca}} \cdot(3.035-2.742)=m_{\mathrm{Ca}} \cdot 0.293 \AA .
$$

As the calculated and measured $d_{104}$ values are, in general, in good accordance, it is most likely that additional $\mathrm{Ca}$ is bound in dolomite structure and expands the lattice parameters.

The presence of $\mathrm{Mn}$ and $\mathrm{Fe}$ in the dolomite structure may also affect the value of $d_{104}$. The impact of $\mathrm{Mn}$ on replacement of $\mathrm{Mg}$ and $\mathrm{Ca}$ is calculated by formulas (3) and (4), respectively:

$$
\begin{aligned}
& \Delta d_{104}=m_{\mathrm{Mn}} \cdot(2.85-2.742)=m_{\mathrm{Mn}} \cdot 0.108 \AA, \\
& \Delta d_{104}=m_{\mathrm{Mn}} \cdot(2.85-3.035)=-m_{\mathrm{Mn}} \cdot 0.185 \AA,
\end{aligned}
$$

where $m_{\mathrm{Mn}}$ is the molar concentration of $\mathrm{MnCO}_{3}$ in dolomite. 
The maximum content of $\mathrm{Mn}$ in samples (Table 1) is $0.14 \mathrm{~mol} \% \mathrm{MnCO}_{3}$. The calculated variation of $d_{104}$ is $0.00015 \AA$ in the case of the replacement of $\mathrm{Mg}$ and $-0.00026 \AA$ in the case of $\mathrm{Ca}$. Both values are below the precision of the method.

The Fe concentrations are in good correlation with the content of insoluble residue (Fig. 2), indicating the precursor to dolomitization origin. The samples declining the main trend are from the intervals of silica lenses (sample 18) or silicified fossils (samples 8a, 9, 12; Table 1). The occurrence of $\mathrm{Fe}$ in the position of $\mathrm{Ca}$ is unlikely. The possible concentration of $\mathrm{Fe}$ in the dolomite lattice is $0.45 \mathrm{~mol} \% \mathrm{FeCO}_{3}\left(0.4 \% \mathrm{Fe}_{2} \mathrm{O}_{3}\right)$. This concentration corresponds to the variation of $d_{104}$ value of $0.0002 \AA$ calculated by (5) and is in the limits of the measurement error:

$$
\Delta d_{104}=m_{\mathrm{Fe}} \cdot(2.79-2.742)=m_{\mathrm{Fe}} \cdot 0.048 \AA .
$$

In the case of the studied dolomites, the enlarged lattice parameters depend on the excess of $\mathrm{Ca}$ in the dolomite structure (Fig. 3a,b).

The content of $\mathbf{S r}$ is low, ranging between 26 and $52 \mathrm{ppm}$ (Table 1, Fig. 3c). It is remarkably less than that of limestones (Fig. 4b) as the entrance of large cations as $\mathrm{Sr}^{+}$into the structure of dolomite is limited because of its smaller lattice parameters. The Sr concentration, increasing the $d_{104}$ value (Fig. 5), covaries evidently with the lithology of the dolomites (Fig. 3c). It is higher in the interval $(3.1-5.7 \mathrm{~m})$ of medium- to coarse-crystalline dolomite and underlying (5.7-6.2 m) yellowish fine-crystalline compact dolomite (see the description of the section). In the case of limestones, the concentration of Sr does not display the lithological differences of rocks; it covaries only with the mol\% of $\mathrm{MgCO}_{3}$

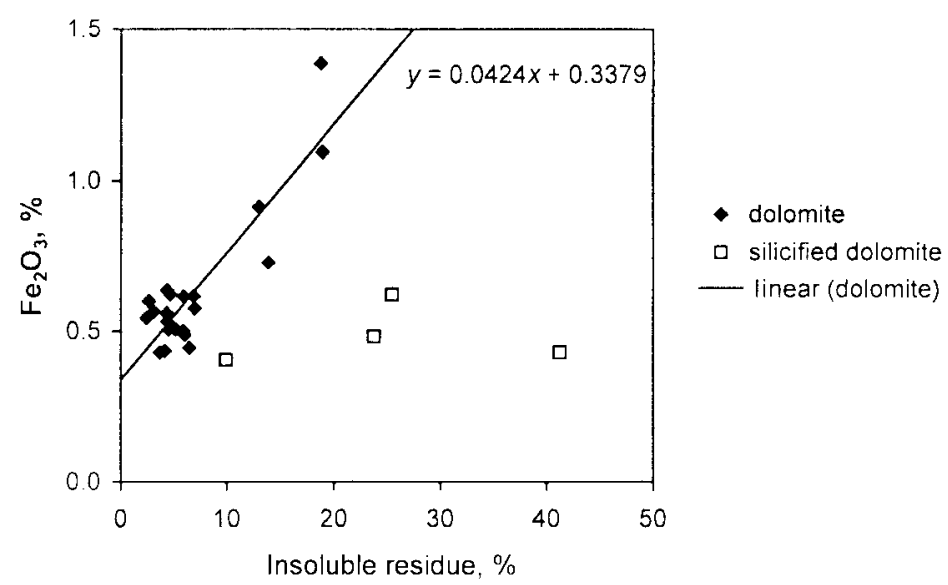

Fig. 2. Correlation of the content of $\mathrm{Fe}_{2} \mathrm{O}_{3}$ (total) and insoluble residue of the dolomites of Rõstla quarry. 
Table 1. Major, minor, and trace element compositions and $d_{104}$ values of the Mõhküla dolomites of Rõstla quarry

\begin{tabular}{|c|c|c|c|c|c|c|c|c|c|c|c|}
\hline \multirow[t]{2}{*}{$\begin{array}{c}\text { Sample } \\
\text { No. }\end{array}$} & \multirow[t]{2}{*}{$\begin{array}{l}\text { Depth, } \\
\mathrm{m}\end{array}$} & \multicolumn{4}{|c|}{ Titration analyses } & \multicolumn{2}{|c|}{$\begin{array}{c}\text { X-ray diffraction } \\
\text { analyses }\end{array}$} & \multicolumn{4}{|c|}{ X-ray fluorescence analyses } \\
\hline & & $\begin{array}{l}\text { insoluble } \\
\text { residue, } \%\end{array}$ & $\mathrm{CaO}, \%$ & $\mathrm{MgO}, \%$ & $\mathrm{CaO} / \mathrm{MgO}$ & $\begin{array}{c}d_{104}, \\
\AA\end{array}$ & $\begin{array}{c}\mathrm{CaCO}_{3}, \\
\mathrm{~mol} \%\end{array}$ & $\begin{array}{l}\mathrm{Mn}, \\
\mathrm{ppm}\end{array}$ & $\begin{array}{l}\mathrm{Sr}, \\
\mathrm{ppm}\end{array}$ & $\begin{array}{l}\mathrm{Pb}, \\
\mathrm{ppm}\end{array}$ & $\begin{array}{c}\mathrm{Fe}_{2} \mathrm{O}_{3} \\
\text { (total), \% }\end{array}$ \\
\hline 1 & 0.10 & 6.00 & 28.49 & 20.09 & 1.42 & 2.8859 & 50.6 & 389 & 27 & 7 & 0.487 \\
\hline 2 & 0.50 & 5.88 & 28.72 & 19.92 & 1.44 & 2.8859 & 50.6 & 417 & 26 & 6 & 0.500 \\
\hline 3 & 1.00 & 6.46 & 28.73 & 19.58 & 1.47 & 2.8865 & 50.8 & 444 & 33 & $<3$ & 0.445 \\
\hline 4 & 1.50 & 4.32 & 28.96 & 20.26 & 1.43 & 2.8860 & 50.7 & 485 & 30 & 3 & 0.558 \\
\hline 5 & 2.00 & 6.88 & 28.25 & 19.75 & 1.43 & 2.8858 & 50.6 & 421 & 28 & 3 & 0.614 \\
\hline 6 & 2.50 & 4.64 & 28.84 & 20.17 & 1.43 & 2.8859 & 50.6 & 482 & 26 & 6 & 0.620 \\
\hline 7 & 2.45 & 93.36 & 1.87 & 1.11 & 1.68 & & & & & & \\
\hline 8 & 3.00 & 4.34 & 29.32 & 20.00 & 1.47 & 2.8853 & 50.4 & 593 & 32 & $<3$ & 0.634 \\
\hline $8 a$ & 3.05 & 25.44 & 23.15 & 15.44 & 1.50 & 2.8859 & 50.6 & 546 & 27 & $<3$ & 0.619 \\
\hline 9 & 3.50 & 9.92 & 27.78 & 18.90 & 1.47 & 2.8859 & 50.6 & 718 & 43 & $<3$ & 0.404 \\
\hline 10 & 4.00 & 2.64 & 29.20 & 20.76 & 1.41 & 2.8854 & 50.5 & 880 & 47 & $<3$ & 0.598 \\
\hline 11 & 3.95 & 4.34 & 29.20 & 20.26 & 1.44 & 2.8857 & 50.6 & 829 & 48 & $<3$ & 0.532 \\
\hline 12 & 4.50 & 23.76 & 23.38 & 15.78 & 1.48 & 2.8858 & 50.6 & 638 & 44 & 4 & 0.482 \\
\hline 13 & 5.00 & 3.10 & 29.44 & 20.51 & 1.44 & 2.8860 & 50.7 & 825 & 49 & $<3$ & 0.563 \\
\hline 14 & 5.50 & 2.42 & 29.56 & 20.85 & 1.42 & 2.8860 & 50.7 & 806 & 50 & $<3$ & 0.544 \\
\hline 15 & 5.70 & 3.68 & 29.91 & 20.26 & 1.48 & 2.8868 & 50.9 & 413 & 49 & 5 & 0.428 \\
\hline 16 & 6.10 & 4.14 & 29.56 & 20.17 & 1.47 & 2.8876 & 51.2 & 445 & 52 & 6 & 0.434 \\
\hline
\end{tabular}


Table 1 continued

\begin{tabular}{|c|c|c|c|c|c|c|c|c|c|c|c|}
\hline \multirow[t]{2}{*}{$\begin{array}{l}\text { Sample } \\
\text { No. }\end{array}$} & \multirow[t]{2}{*}{$\begin{array}{c}\text { Depth, } \\
\mathrm{m}\end{array}$} & \multicolumn{4}{|c|}{ Titration analyses } & \multicolumn{2}{|c|}{$\begin{array}{l}\text { X-ray diffraction } \\
\text { analyses }\end{array}$} & \multicolumn{4}{|c|}{ X-ray fluorescence analyses } \\
\hline & & $\begin{array}{l}\text { insoluble } \\
\text { residue, } \%\end{array}$ & $\mathrm{CaO}, \%$ & $\mathrm{MgO}, \%$ & $\mathrm{CaO} / \mathrm{MgO}$ & $\begin{array}{c}d_{104}, \\
\AA \\
\end{array}$ & $\begin{array}{c}\mathrm{CaCO}_{3}, \\
\mathrm{~mol} \%\end{array}$ & $\begin{array}{l}\mathrm{Mn}, \\
\mathrm{ppm}\end{array}$ & $\begin{array}{c}\mathrm{Sr}, \\
\mathrm{ppm}\end{array}$ & $\begin{array}{l}\mathrm{Pb}, \\
\mathrm{ppm}\end{array}$ & $\begin{array}{c}\mathrm{Fe}_{2} \mathrm{O}_{3} \\
\text { (total), \% }\end{array}$ \\
\hline 17 & 6.50 & 4.48 & 29.44 & 20.09 & 1.47 & 2.8860 & 50.7 & 527 & 33 & 13 & 0.505 \\
\hline 18 & 6.55 & 41.24 & 18.28 & 12.32 & 1.48 & 2.8861 & 50.7 & 341 & 25 & 10 & 0.429 \\
\hline 19 & 6.80 & 96.80 & 1.04 & 0.54 & 1.93 & & & & & & \\
\hline 20 & 7.30 & 5.14 & 29.20 & 19.92 & 1.47 & 2.8860 & 50.7 & 503 & 32 & $<3$ & 0.505 \\
\hline 21 & 7.80 & 5.90 & 29.05 & 19.83 & 1.46 & 2.8860 & 50.8 & 490 & 33 & 3 & 0.613 \\
\hline 22 & 7.50 & 6.96 & 28.96 & 19.07 & 1.52 & 2.8865 & 50.7 & 581 & 45 & 3 & 0.575 \\
\hline 23 & 8.10 & 18.90 & 24.69 & 15.87 & 1.56 & 2.8868 & 50.9 & 354 & 42 & 8 & 1.094 \\
\hline 24 & 8.40 & 13.84 & 26.00 & 17.98 & 1.45 & 2.8868 & 50.9 & 381 & 47 & 20 & 0.728 \\
\hline 25 & 8.80 & 12.98 & 26.59 & 17.98 & 1.48 & 2.8865 & 50.8 & 494 & 41 & $<3$ & 0.912 \\
\hline 26 & 9.10 & 18.74 & 24.57 & 16.80 & 1.46 & 2.8870 & 51.0 & 358 & 44 & 5 & 1.386 \\
\hline $\mathrm{k} 1,9^{*}$ & & & & & & & & 335 & 26 & 6 & 0.305 \\
\hline $\mathrm{k} 2,4,6^{*}$ & & & & & & & & 299 & 34 & 10 & 0.348 \\
\hline $\mathrm{k} 5 *$ & & & & & & & & 273 & 33 & $<3$ & 0.327 \\
\hline $\mathrm{k} 3,7,8^{*}$ & & & & & & & & 311 & 43 & 8 & 0.394 \\
\hline
\end{tabular}

* samples of the dolomites of the Muhu Formation of Kurevere quarry (after Teedumäe et. al. 1999) 
(a)

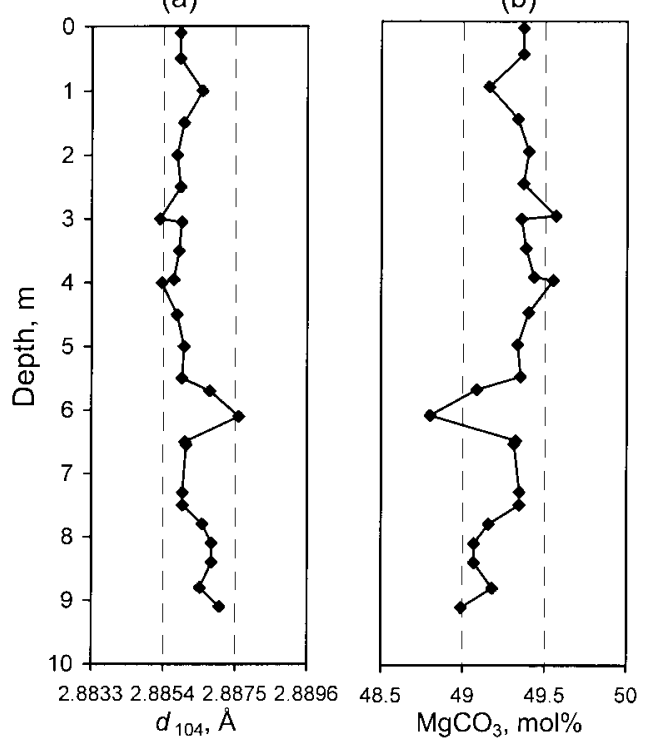

(c)

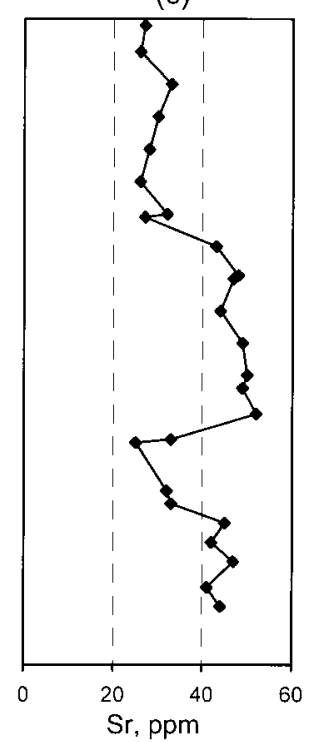

(d)

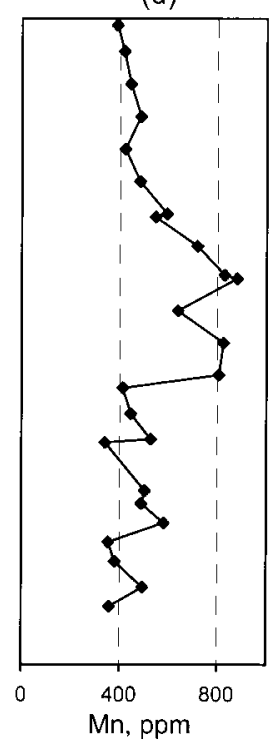

Fig. 3. Variation of $d_{104}$ (a), $\mathrm{MgCO}_{3}$ (b), $\mathrm{Sr}$ (c), and $\mathrm{Mn}$ (d) vs. depth of the dolomites of Rõstla quarry.

(a)

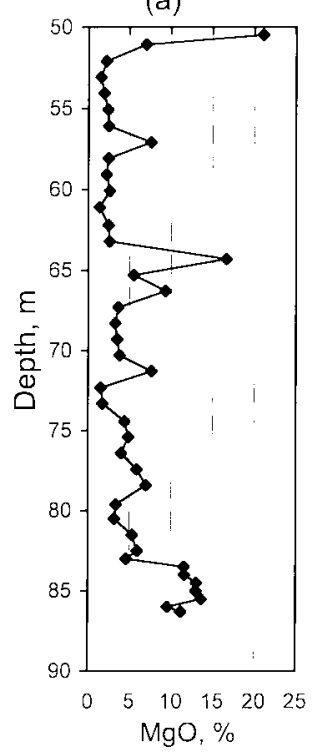

(b)

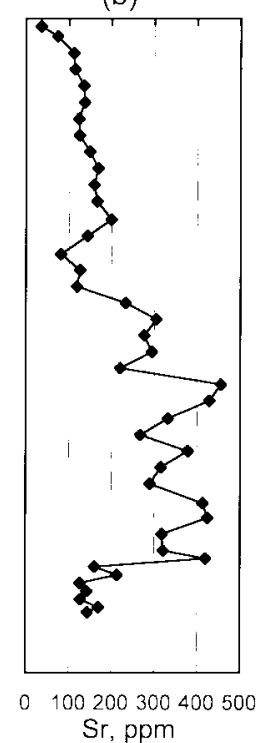

(c)

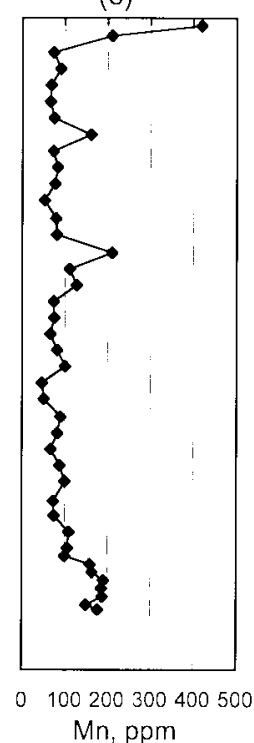

Fig. 4. Variation of $\mathrm{MgO}$ (a), $\mathrm{Sr}(\mathrm{b})$, and $\mathrm{Mn}$ (c) vs. depth of the limestones of the Kirikuküla borehole. 


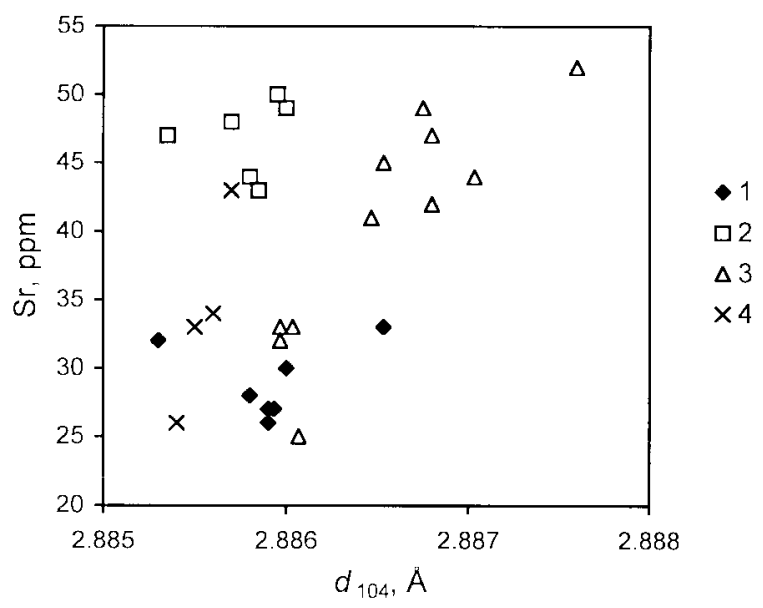

Fig. 5. Correlation of the concentration of $\mathrm{Sr}$ and $d_{104}$. Dolomites of Mõhküla quarry: 1 , upper finecrystalline dolomite; 2 , medium- to coarse-crystalline dolomite; 3, lower fine-crystalline dolomite; 4, dolomite of Kurevere quarry (Muhu Formation, Wenlock, Silurian).

(Fig. 4a,b). The covariation of $\mathrm{Sr}$ with the $\mathrm{mol} \%$ of $\mathrm{MgCO}_{3}$ in dolomites is observable only in the interval below $6.2 \mathrm{~m}$ (Fig. 3b,c). This allows us to suggest that the fluctuation of the concentration of $\mathrm{Sr}$ along the section results from the process of dolomitization.

The low Sr concentrations in carbonates have been attributed to meteoricmarine mixing prior to carbonate precipitation (McNutt et al. 1987; Banner et al. 1988), modification during diagenesis (Morrow \& Mayers 1978; Land 1985), and deep hypersaline brines (Simo et al. 1994).

All lithological varieties of the Mõhküla dolomites plot as a group (Fig. 6) near the line for sea water dolomite proposed in Vahrenkamp \& Swart (1990). The rate of modification of sea water is complicated to estimate, but all the evidences indicate that it could not have been high.

The content of Mn in dolomites is between 354 and $880 \mathrm{ppm}$ (Table 1), that is about four times higher than in the limestones of the Kirikuküla core (Fig. 4c). The medium- to coarse-crystalline dolomite is enriched in Mn with respect to fine-crystalline dolomite (Fig. 3d). These variations can be related to a reducing environment, with the fluctuations either in the supply of Mn or Eh. A reducing environment is required to bring $\mathrm{Mn}$ (and $\mathrm{Fe}$ ) into the water and incorporate it into coarse-crystalline dolomite (Mutti \& Simo 1994). The lower crystallization rate of coarse-crystalline dolomite may also cause a higher Mn content.

The correlation of the concentration of $\mathrm{Mn}$ with the content of $\mathrm{Fe}_{2} \mathrm{O}_{3}$ is, in general, positive. An exception is the highly argillaceous dolomite (interval 8.10-9.10 m, Table 1, Fig. 7). 


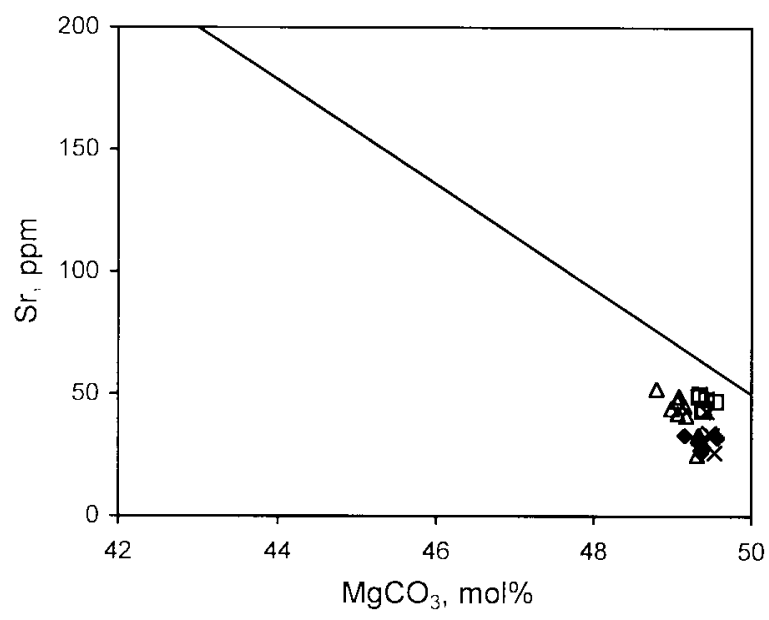

Fig. 6. Sr vs. $\mathrm{MgCO}_{3}$. Sea water dolomite line after Vahrenkamp \& Swart (1990). For legend see Fig. 5.

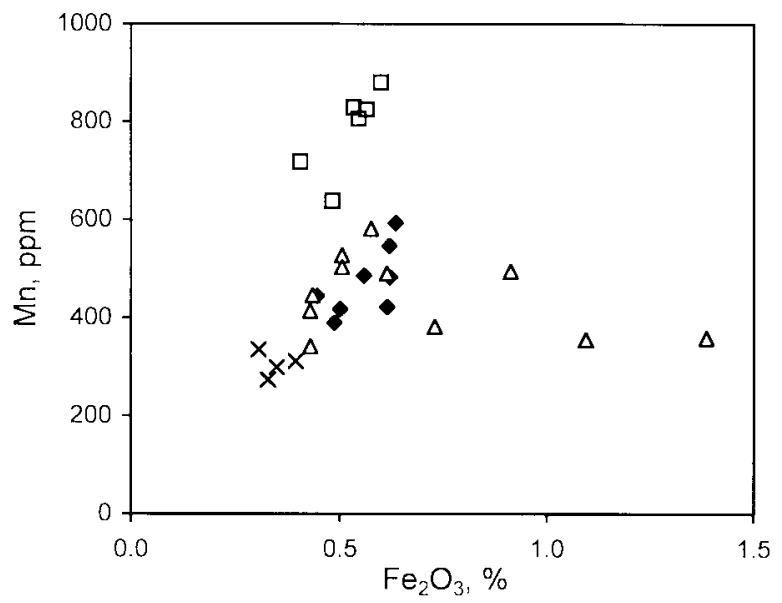

Fig. 7. Correlation of $\mathrm{Mn}$ and $\mathrm{Fe}_{2} \mathrm{O}_{3}$ (total) concentrations. For legend see Fig. 5.

The distinct positive correlation of $\mathrm{Mn}$ and $\mathrm{Sr}$ is somewhat unexpected (Fig. 3c,d). It differs between various rock types and is not observed in the Muhu dolomites (Wenlock) of the Kurevere deposit (Fig. 8).

In general, the Mõhküla dolomites originating from normal-marine fossil-rich carbonates are depleted in $\mathrm{Sr}$ and enriched in $\mathrm{Mn}$ in comparison with the limestones of the same origin. The content of iron compounds equals that of limestones. Differences in the element concentrations and their correlations in 


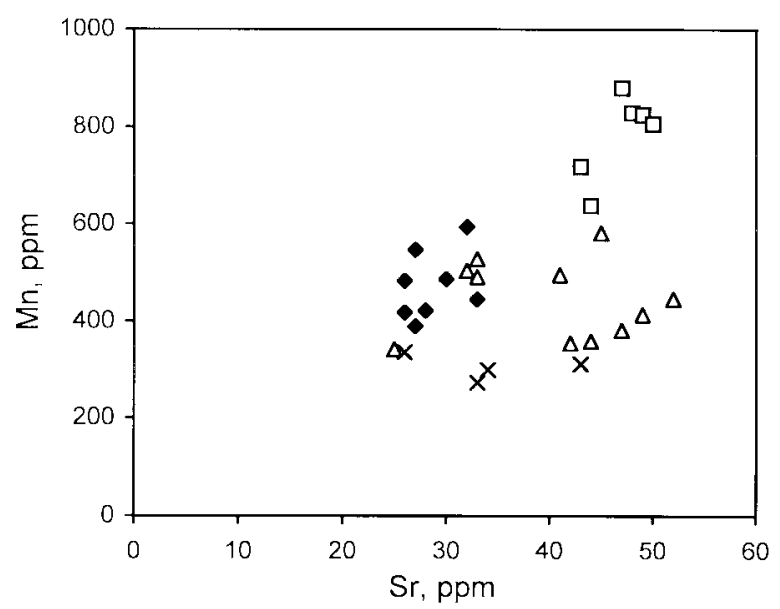

Fig. 8. Correlation of $\mathrm{Mn}$ and $\mathrm{Sr}$ concentrations. For legend see Fig. 5.

individual rock types reflect the differences in the environment and relative timing of dolomitization. This supports the suggestion that there was no unique dolomitizing fluid and dolomitization began soon after the deposition. In all probability, the process proceeded due to relic sea water under varying hydrochemical conditions even in the post-Silurian. Partially leached fragments of fossils and irregular solution cavities not related to organic forms suggest that dissolution was part of the dolomitization process.

The palaeoenvironment as a multicomponent system has its own regulations and correlations between numerous simultaneously acting palaeofactors, which at present can be interpreted only in general. Detailed reconstruction of definite episodes or events remains suppositional because of the hypothetical character of a great number of basic parameters such as salinity, temperature, deposition, and crystallization rates, relative sea level variations, impact of organic matter, etc.

Correlation of the localization of dolomitization with the distribution of sediments and facies belts at different stages of the evolution of the Silurian palaeobasin (Nestor \& Einasto 1997) allows us to suggest that dolomitization in general is associated with regression periods and is related to the inner shelf facies, whereas the outer shelf and deeper basin facies are undolomitized. The area favourable for dolomitization most probably migrated basinward and landward in accordance with cyclic fluctuation of sea level and oscillation of the shoreline.

The relatively well preserved primary lithological characteristics (Jürgenson 1970; Teedumäe 1996), low porosity (Teedumäe 1996), low content of $\mathrm{Fe}$ compounds and their positive correlation with the insoluble residue, also the high degree of crystallographic ordering of all lithological varieties indicate the 
relatively early diagenetic (prior to complete lithification) dolomitization. The late Llandovery limestones, unconformably overlapping the middle Llandovery dolomites (Kirikuküla core, Kaljo 1970, p. 241; Nurme core, Nestor 1997, p. 93; and others) also indicate early dolomitization.

In the case of relatively early diagenetic dolomitization water ought to have circulated continuously, or repeatedly, through the upper part of the slowly accumulating unlithified sediments during a considerable time (Kruger \& Simo 1994). The duration of the Monograptus convolutus graptolite Zone corresponding to the Mõhküla Beds was about 1.5 Ma (Carter et al. 1980); the sedimentation rate for consolidated sediments did not exceed $10 \mathrm{~mm}$ per $1000 \mathrm{yr}$ (Lindström 1971). Although at the end of the middle Llandovery the northwestwards increasing hiatus formed a single erosional surface, it probably resulted from small-scale oscillations of shoreline against the background of progressive sea level drop, which favoured the circulation of water through sediments.

\section{CONCLUSIONS}

The rocks of the Mõhküla Beds are uniformly dolomitized. The geological data confirm the origin of the Mõhküla dolomites from the normal-marine carbonate sediments of the inner shelf facies of the gulf-like pericratonic sea.

Dolomitization associates with the cyclically progressing regression stage (early-middle Llandovery macrocycle) of the Baltic Palaeobasin, ending with sedimentation breaks and denudation. It was a long-lasting process, enabling almost total replacement of the precursor calcite within the whole of the Mõhküla Beds. The $\mathrm{CaCO}_{3} / \mathrm{MgCO}_{3}$ molar ratio and lattice parameters of dolomites, irrespective of the content of insoluble residue or the texture of rocks, are close to those of ideal dolomites.

In general, dolomites are depleted in $\mathrm{Sr}$ and enriched in $\mathrm{Mn}$. The concentrations and correlations, however, vary between lithological varieties, which refers to differences in the dolomitizing environment. This supports the suggestion that there was no unique dolomitizing fluid and the dolomitization occurred both soon after the deposition as well as during numerous breaks in carbonate sedimentation and the denudation period at the end of the middle Llandovery. Due to the relic sea water it might have proceeded even later. Low porosity, low contents of $\mathrm{Pb}$ and $\mathrm{Fe}$ compounds, well preserved primary lithological characteristics of dolomites, and facies-related localization of dolomitization support the supposition of early (prior to complete lithification) dolomitization. The disconformable overlap of middle Llandovery dolomites by late Llandovery limestones also indicates dolomitization in the middle Llandovery or during the denudation at the end of the middle Llandovery. The area favourable for dolomitization in all probability migrated in accordance with the fluctuation of sea level and oscillation of the shoreline, but stayed in the limits of the inner shelf. 
The geochemistry of dolomites is consistent with dolomitization by sea water or modified sea water, and it reflects the differences in the environment of this long-lasting process. The cyclicity of the evolution of the Baltic Basin in the Silurian provided the necessary circulation of this major dolomitizing medium through sediments. Partially leached fragments of fossils and irregular solution cavities suggest that dissolution was part of the dolomitization process.

Later, different processes of mineralization (including dolomitization and karstification) have locally altered rocks along the fracture and disturbance zones. The study of the composition of fracture-related dolomites against the background of spacious early diagenetic dolomites provides a basis for estimating their extent, origin, and timing.

\section{ACKNOWLEDGEMENTS}

This study was supported by the governmental target funding (project No. 0140226Bs98). The titration analyses of dolomite were performed in the laboratory of the Geological Survey of Estonia. The authors thank E. Pirrus for assistance in collecting samples from Rõstla quarry, D. Kaljo and H. Nestor for very useful comments, V. Puura for the critical reading of the manuscript, and H. Kukk for linguistic corrections.

\section{REFERENCES}

Banner, J. L., Hanson, G. N. \& Meyers, W. J. 1988. Water-rock interaction history of regionally extensive dolomites of the Burlington-Keokuk Formation (Mississippian) isotopic evidence. In Sedimentology and Geochemistry of Dolostones (Shukla, V. \& Baker, P. A., eds.). Spec. Publ. Soc. Econ. Paleont. Mineral., 43, 97-113.

Bityukova, L., Shogenova, A. \& Götze, H.-J. 1998. Influence of chemical composition on petrophysical properties of Early-Paleozoic carbonate rocks in Estonia. Phys. Chem. Earth, 23, 309-316.

Carter, C., Trexler, J., Jr. \& Churkin, M., Jr. 1980. Dating of graptolite zones by sedimentation rates: implications for rates evolution. Lethaia, 13, 273-287.

Jürgenson, E. 1966. Litologiya llandoverijskikh otlozhenij Éstonii. ENSV TA Geol. Inst., Tallinn (in Russian).

Jürgenson, E. 1970. Secondary alteration of rocks. In Silur Éstonii (Kaljo, D., ed.), pp. 96-100. Valgus, Tallinn (in Russian).

Jürgenson, E. 1988. Osadkonakoplenije v silure Pribaltiki. Valgus, Tallinn (in Russian).

Kaljo, D. 1970. Adavere Stage. In Silur Éstonii (Kaljo, D., ed.), pp. 232-243. Valgus, Tallinn (in Russian).

Kiipli, T. 1983. On the genesis of Ordovician and Silurian dolomites at the contact with Devonian deposits. Eesti NSV TA Toim. Geol., 32, 110-117 (in Russian).

Kruger, J. M. \& Simo, J. A. 1994. Pervasive dolomitization of subtidal carbonate ramp, Silurian and Devonian, Illinois Basin, USA. In Dolomites (Purser, B., Tucker, M. \& Zenger, D., eds.), pp. 387-405. Blackwell Sci. Publ., Oxford.

Land, L. S. 1985. The origin of massive dolomite. J. Geol. Educ., 33, 112-125. 
Lindström, M. 1971. Vom Anfang, Hohstand und Ende eines Epikontinentalmeeres. Geol. Rundschau, 60, 419-438.

McNutt, R. H., Frape, S. K. \& Dollar, P. 1987. A strontium, oxygen and hydrogen isotopic composition of brines, Michigan and Appalachian basins. App. Geochem., 2, 495-505.

Morrow, D. V. \& Mayers, I. R. 1978. Simulation of limestone diagenesis - a model based on strontium depletion. Can. J. Earth Sci., 15, 376-396.

Mutti, M. \& Simo, J. A. 1994. Distribution, petrography and geochemistry of early dolomite in cyclic shelf facies, Yates Formation (Guadalupian), Captain Reef Complex, USA. In Dolomites (Purser, B., Tucker, M. \& Zenger, D., eds.), pp. 91-110. Blackwell Sci. Publ., Oxford.

Nestor, H. 1995. Comments to the modernized Silurian correlation chart of Estonia and Latvia. Geologija, 17, 88-95.

Nestor, H. 1997. Raikküla Stage. In Geology and Mineral Resources of Estonia (Raukas, A. \& Teedumäe, A., eds.), pp. 94-95. Estonian Acad. Publ., Tallinn.

Nestor, H. \& Einasto, R. 1997. Ordovician and Silurian carbonate sedimentation basin. In Geology and Mineral Resources of Estonia (Raukas, A. \& Teedumäe, A., eds.), pp. 192-204. Estonian Acad. Publ., Tallinn.

Simo, I. A., Johnson, M. R., Vandrey, M. R., Brown, P. E., Castrogiovanni, E., Drzewieky, J. W., Valley, J. W. \& Boyer, J. 1994. Burial dolomitization of the Middle Ordovician Glenwood Formation by evaporitic brines. In Dolomites (Purser, B., Tucker, M. \& Zenger, D., eds.), pp. 169-184. Blackwell Sci. Publ., Oxford.

Teedumäe, A. 1992. Possibilities of the application of carbonate rocks of the Raikküla Formation (Silurian, Estonia). Proc. Estonian Acad. Sci. Geol., 41, 63-72.

Teedumäe, A. 1996. Carbonate rocks of the Adavere Stage and possibilities of their utilization. Proc. Estonian Acad. Sci. Geol., 45, 22-33.

Teedumäe, A., Kiipli, T. \& Kallaste, T. 1999. Dolomites of the Muhu Formation (Silurian) in mainland Estonia: aspects of dolomitization, properties, and prospects of utilization. Proc. Estonian Acad. Sci. Geol., 48, 213-227.

Vahrenkamp, V. C. \& Swart, P. K. 1990. New distribution coefficient for the incorporation of dolomite and its implicates for the formation of ancient dolomite. Geology, 18, 387-391.

Vishnyakov, S. G. 1956. Genetic types of dolomitic rocks in the northwestern margin of the Russian Platform. Tr. geol. in-ta AN SSSR, 4, 209-255 (in Russian).

\section{MÕHKÜLA KIHTIDE (SILUR) DOLOMIIDISTUMISE ASPEKTID}

\section{Aada TEEDUMÄE, Toivo KALLASTE ja Tarmo KIIPLI}

Mõhküla kihistu dolomiidid (Kesk-Llandovery ülemine osa) moodustavad siluriaegsete normaalmereliste lubisetete (Llandovery, Wenlock) faatsiesi lõikava lausdolomiidistunud kivimkeha keskmise osa.

Dolomiitide $\mathrm{CaCO}_{3}$ ja $\mathrm{MgCO}_{3}$ molaarne suhe ja võreparameetrid on lähedased ideaaldolomiidi omadele. Mikroelementide kooslus viitab dolomiidistumisele merevee toimel. Rauaühendite sisaldus on madal ja korreleerub nii nagu normaalmerelistel lubjakividelgi positiivselt lahustumatu jäägi sisaldusega.

Mõhküla dolomiidid on kõigi eelduste kohaselt tekkinud algselt normaalmereliste lubisetete dolomiidistumisel varase diageneesi käigus basseini regressiivse arengufaasi ajal. Tsüklilised veepinna kõikumised Llandoverys ja Wenlockis 
ning hulgalised settekatkestused aktiviseerisid merevee liikumist läbi setete, soodustades sellega nende varajast dolomiidistumist. Veepinna kõikumistest tulenevalt migreerus dolomiidistumiseks soodne ala ranniku ja avašelfi vahel. Selle tulemusel moodustus faatsiesi lõikav dolomiidikeha.

\section{АСПЕКТЫ ДОЛОМИТИЗАЦИИ МЫХКЮЛАСКИХ СЛОЕВ (СИЛУР, ЭСТОНИЯ)}

\section{Аада ТЭЭДУМЯЭ, Тойво КАЛЛАСТЕ и Тармо КИЙПЛИ}

Доломиты мыхкюласких слоев составляют верхи среднего лландовери на северо-восточной окраине Балтийского палеобассейна, образуя среднюю часть крупного, прорезающего фации тела вторичных доломитов. Мыхкюлаские доломиты имеют молярное соотношение $\mathrm{CaCO}_{3} / \mathrm{MgCO}_{3}$ и межплоскостные параметры, близкие к идеальным. Ассоциация микроэлементов указывает на доломитизацию в морской среде. Низкое содержание соединений железа и их положительная корреляция с содержанием нерастворимого остатка идентичны тем же показателям известняков нормально-морского происхождения. Доломиты мыхкюласких слоев образовались в ходе раннего диагенеза первично нормально-морских известковых осадков регрессивной фазы палеобассейна. Цикличность эвстатических колебаний и частые перерывы в осадконакоплении в лландовери и венлоке активизировали движение морской воды сквозь осадки, благоприятствуя тем самым доломитизации, зона которой мигрировала между береговой зоной и открытым шельфом согласно эвстатике, что и привело к образованию крупного, прорезающего фации тела доломитов. 